\title{
MODEL PENDEKATAN GURU DALAM OPTIMALISASI CLASS ROOM MANAGEMENT DI MADRASAH IBTIDAIYAH
}

\author{
Zumrotus Sa'diyah \\ IAI Sunan Giri Bojonegoro \\ Zumrotus.sadiyah@gmail.com
}

\begin{abstract}
This study was conducted with the aim of describing the approach model used by teachers in optimizing the implementation of class room management as an effort to shape learning in Islamic elementari school Madrasah Ibtidaiyah (MI), to describe the extent of student responses to the model used by teachers in optimizing the implementation of class room management. The design used in this study is case study research to describe the phenomena and facts that occur in the learning process in the classroom through non-participant observation activities, interviews and questionnaires with student respondents on teaching and learning activities undertaken by teachers and students at MI Al Asyhar Jelu Ngasem Bojonegoro. The validity of the data obtained using the method of triangulation of sources, and techniques are then analyzed to get conclusions. The results of the research that have been done show that classroom room management has a strategic role in creating efficient learning, through several stages, namely; planning, organizing, implementing and evaluating learning. As the results of the study show that under class room management that has been applied at MI Al Asyhar has a very strategic role, it is supported by the recognition of students as respondents taken through questionnaires, with the results of $89 \%$ of students feeling that the classroom management room teacher is applying a humanistic model, and democratic authority models by $84 \%$, and behavioristic models 78\%. Learning will be more fun and successful if the use of class room management maximizes and combines the advantages of the three models.
\end{abstract}

Keywords: teacher approach, class room management.

\begin{abstract}
Abstrak
Penelitian ini dilakukan dengan tujuan untuk mendeskripsikan model pendekatan yang digunakan guru dalam optimalisasi implementasi class room management sebagai upaya membentuk pembelajaran yang evisien di Madrasah Ibtidaiyah (MI), untuk mendeskripsikan sejauh mana respon siswa terhadapmodel yang digunakanoleh guru dalamoptimalisasi implementasi class room management. Desain yang digunakan dalam penelitian ini case study research untuk mendeskripsikan fonomena dan fakta yang terjadi dalam proses pembelajaran di kelas melalui kegiatan observasi non partisipan, wawancara dan angket dengan responden siswa terhadap kegiatan belajar mengajar yang dilakukan guru dan siswa di MI Al Asyhar Jelu NgasemBojonegoro.
\end{abstract}


Adapun validitas data yang diperoleh menggunakan metode triangulasi sumber, dan teknik kemudian dianalisis sehingga mendapatkan kesimpulan. Hasil dari penelitian yang telah dilakukan menunjukan bahwa class room managemen sangat memiliki peran yang strategis dalam menciptakan pembelajaran yang evisien, melalui beberapa tahapan yaitu; perencanaan, pengorganisasian, pelaksanaan dan evaluasi belajar. Sebagaimana hasil penelitian menunjukan bawah class room management yang telah diterapkan di MI Al Asyhar memiliki peran yang sangat setrategis, hal itu didukung dengan pengakuan siswa sebagai responden yang diambil melalui angket, dengan hasil 89\% siswa lebih merasakan bahwa class room managemen guru menerapkan model humanistis, dan model otoritas demokratis sebesar $84 \%$, dan model behavioristik $78 \%$. Pembelajaran akan semakin menyenangkan dan berhasil bila penggunaan class room management memaksimalkan serta mengkombinasikan keunggulan ketiga model tersebut.

Kata Kunci: pendekatan guru, class room management.

\section{Pendahuluan}

Kelas merupakan fasilitas tempat dilaksanakan proses belajar mengajar, meskipun tidak semua pembelajaran harus dilaksanakan di dalam kelas. Dalam satuan pendidikan kelas dianggap fasilitas yang wajib ada dalam proses pembelajaran, oleh karena itu guru harus memiliki kompetensi dalam melaksanakan tugas serta seorang guru harus memiliki ketrampilan class room management dan pembelajarannya secara profesional. Pendidikan madrasah ibtidaiyah dewasa ini memiliki tantangan tersendiri yaitu berupaya untuk menemukan kembali pentingnya karakter seperti kemampuan beradaptasi, ketekunan, ketahanan, cinta lingkungan dan sifat- sifat moral yang terkait dengan integritas, keadilan, empati serta etika yang baik. ${ }^{1}$ Karakter sekolah salah satunya dapat dibangun dengan optimalisasi class room management dalam hal ini menjadi tanggung jawab penuh guru dan lembaga pendidikan. Ungkapan tersebut menekankan bahwa tugas guru diharapkan mampu menghasilkan peserta didik yang memiliki ilmu pengetahuan serta berkarakter sehingga mampu menghadapi arus globalisasi dan perkembangan jaman di abad 21. Hal tersebut juga sejalan dengan tuntutan kurikulum 2013 yang berbasis karakter. Pembangunan karekter

\footnotetext{
${ }^{1}$ Scheicher, A. (2012). Preparing teachers and developing school leaders for thes1st century: Lessons from around te world. New York: OECD Publishing. Hal 14
} 
siswa dalam belajar tidak hanya tergantung dari satu aspek tetapi multi karena pada dasarnya proses belajar tidak terbatas pada guru dan kurikulum saja tetapi erat kaitannya dengan semua aspek secara integral dan holistikan yang menciptakan kondisipembelajarandikelas. ${ }^{2}$

Guru sangat berperan dalam menentukan keberhasilan siswa dalam proses pembelajaran karena gurulah yang menciptakan suasana proses pembelajaran yang menyenangkan serta mengatasi problematika pembelajaran di kelas. Class room management merupakan inti kegiataan peroses belajar mengajar baik bersifat instruksional maupun managerial, dalam hal ini membutuhkan kreatifitas guru dalam optimalisasi class room management untuk mencapai tujuan pembelajaran yang ingin dicapai. Namun, faktanya di daerah-daerah pelaksanaan proses pembelajaran masih bersifat konvensional walaupun guru memegang otoritas penuh dalam pembelajaran. Terlihat ruang kelas yang monoton lebih dominan dengan tata meja dan kursi yang paten dan cukup sempit membuat guru selalu melaksanakan proses pembelajaran dikelas dengan skenario belajar satu arahdan homogen tidak dengan beberapa variasi seperti pola duduk berbaris, $\mathrm{O}, \mathrm{U}$ dan T.

Terkait peran guru pengajar dan pendidik, masih terlihat kurang memahami tentang class room management yang baik. Guru masih memfokuskan dengan target materi yang padat sebagaimana yang tertera dalam kurikulum; masih nampak bahwa profesi guru memerankan tugasnya sebagai rutinitas pekerjaan saja. Sekolah sebagai tempat proses pembelajaran berlangsung bagi siswa, serta tugas guru yang utama adalah dikelas.

Proses kegiatan belajar mengajar gurulah ujung tombak penentu ketercapian pembelajaran, untuk itu harus seorang guru harus memiliki dedikasi yang tinggi, menguasai ilmu pengetahuan, cerdas menentukan tindakan yang tepat terhadap setiap permasalahan pendidikan yang dihadapi, mampu memenuhi tuntutan kurikulum serta memiliki kreatifitas tinggi dalam mengelola kelas untuk menciptakan pembelajaran yang efisien, kondusif dan menyenangkan bagi siswa.

\footnotetext{
${ }^{2}$ Dike, D., \& Parida, L. (2016). Persepsi dan konsepsi mutu pendidikan sekolah dasar.Pendidikan Dasar PerKhasa, 2(2), 204-205
} 


\section{Metode}

Penelitian ini menggunakan pendekatan penelitian kualitatif dengan jenis penelitian case study research, karena memfokuskan pada fenomena dan realitasyang terjadi untuk dapat dikaji lebih lanjut, yakni menjayikan realitas subjek yang diteliti serta keunikan situasionalnya. ${ }^{3}$ Pengalaman nyata yang dimaksud dalam penelitian ini ialah, situasi belajar dan infrastruktur kelas serta kreatifitas guru dalam melaksanakan class room management.

Penelitian ini dilaksanakan di Madrasah Ibtidaiyah Al Asyhar yang bertempat di dusun Prajekan Desa Jelu Kecamatan Ngasem Kabupaten Bojonegoro pada kelas bawah dan atas yaitu, kelas III, IV dan V. Penelitian studi kasus ini memfokuskan pada kreatifitas guru dalam melaksanakan class room management dengan melihat apa, mengapa dan bagaimana class room management itu diterapkan dalam pembelajaran sehari-hari guru di kelas. ${ }^{4}$

Sedangkan siswa dalam penelitian ini sebagai subyek pembanding untuk menentukan umpan balik terhadap implementasi class room management yang didesain peneliti melalui angket dengan responden siswa. Selain angket penggalian data juga dilakukan dengan wawancara dengen beberapa nara sumber tentang tiga aspek kreatifitas guru dalam pelaksanaan class room management yakni, humanistic, demokratik dan behavioristic. Desain fenomenologi ini menggabungkan berbagai data baik dari observasi, wawancara, angket dan dokumen, kemudian dilakukan diseminasi sehingga memperkuat validitas hasil penelitian.

\section{Hasil dan pembahasan}

Sebagaimana analisis yang telah dilakukan, penelitian ini menghasilkan deskripsi aspek sebagaimana rumusan pertanyaan peneitian yakni bagaimana peran kreatifitas guru dalam class room management pada proses pembelajaran di

\footnotetext{
${ }^{3}$ Stake, R. E. (2005). Qualitative case studies. In N. K. Denzin \& Y. . Lincoln (Eds.), The Sage Handbook of Qualitative Research Thousand Oaks, CA.: Sage Publications Ltd. H.443-445

${ }^{4}$ Ary, D., Jacobs, L. C., Sorensen, C., \& Razavieh, A. (2006).Introduction to research in education (eight). Belmont: wadsworth Cengage Learning. H 29
} 
Madrasah Ibtidaiyah (MI)? serta dampak yang dihasilkan dari pelaksanaan tersebut? Secara rinci hasil dan kajian aspek-aspek tersebut diuraikan sebagai berikut.

\section{Hasil Pengelolaan Kelas Model Humanistik}

Sebagaimana hasil wawancara dan observasi pada proses pembelajaran di kelas III, IV dan V pelaksanaan class room management model humanistic dapat direkam dengan jelas melalui tabel berikut ini:

\begin{tabular}{|l|l|l|l|}
\hline \multicolumn{7}{|c|}{ Tabel 1. Kondisi dan Tindakan Model Humanistik Guru } \\
Kelas
\end{tabular}




\section{Penggelolaan Kelas Model Demokratik}

Sebagaimana hasil wawancara dan observasi pada proses pembelajaran di kelas III, IV dan V pelaksanaan class room management model demokratis dapat dilihat dengan jelas melalui tabel berikut ini:

Tabel 2. Implementasi Model Demokratik Guru Dalam Pembelajaran

\begin{tabular}{|c|c|c|}
\hline Management & Tindakan & Hasil \\
\hline $\begin{array}{c}\text { Model } \\
\text { Demokratik }\end{array}$ & $\begin{array}{l}\text { a) Melakukan presensi kepada siswa diawal } \\
\text { pembelajaran. } \\
\text { b) Membagi tugas piket yang adil untuk } \\
\text { melatih hidup bersih, tanggung jawab dan } \\
\text { kerjasama antar teman. } \\
\text { c) Menentukan dan merotasi posisi duduk } \\
\text { secara berkala. } \\
\text { d) Menyediakan dan m e m f a s i l i t a s } \\
\text { m i n a t d a n b a k a t s i s w a } \\
\text { b a i k a k a d e m i k m a u p u n } \\
\text { n o n a k a d e m i k m e l a } 1 \text { u i } \\
\text { k e g i a t a n } \\
\text { e k s t r a k u l i k u l e r, s e r t a } \\
\text { memberikan kebebasan siswa dalam } \\
\text { pilihan kegiatan ekstrakulikuler yang akan } \\
\text { mereka ikuti. } \\
\text { e) Memberi kebebasan siswa dalam memilih } \\
\text { pengurus kelas adapaun pelaksanaanya } \\
\text { diarahkan oleh guru } \\
\text { f) Guru memberikan reward kepada siswa } \\
\text { yang berprestasi dalam bidang akademik } \\
\text { maupun non akademik, serta memberi } \\
\text { hukuman kepada siswa yang tidak } \\
\text { mentaati aturan sekolah. } \\
\text { g) Menjalin hubungan dan komunikasi yang } \\
\text { baik dengan orang tua siswa } \\
\text { h) Membentuk kelompok belajar yang } \\
\text { hiterogen }\end{array}$ & $\begin{array}{l}\text { Perencanaanya sangat baik: } \\
\text { a) Kegiatan presensi berjalan secara } \\
\text { rutin. } \\
\text { b) Siswa antusias menjalankan } \\
\text { tanggungjawabnya untuk } \\
\text { membersihkan kelas. } \\
\text { c) Siswa sangat setuju merotasi } \\
\text { tempat duduk mereka yang } \\
\text { dilaksanakan sesuai kebutuhan } \\
\text { d) Siswa sangat antusias mengikuti } \\
\text { kegiatan ekstrakulikuler, serta } \\
\text { didukung sepenuhnya oleh orang tua. } \\
\text { e) Pemilihan pengurus kelas tampak } \\
\text { hasil musyawarah dan voting } \\
\text { f) Siswa termotivasi untuk berlomba- } \\
\text { lomba berprestasi dalam bidang } \\
\text { akademik maupun non akademik, } \\
\text { serta hukuman dapat menertibkan } \\
\text { siswa. } \\
\text { g) forum komunikasi antar sekolah } \\
\text { dengan orang tua untuk membahas } \\
\text { permasalahan dan menampung } \\
\text { aspirasi wali murid. } \\
\text { h) Memberikan hak dan kesempatan } \\
\text { yang adil kepada siswa }\end{array}$ \\
\hline
\end{tabular}




\section{Penggelolaan Kelas Model Behavioristik}

Sebagaimana hasil wawancara dan observasi pada proses pembelajaran di kelas III, IV dan V pelaksanaan class room management model behavioristik dapat dilihat dengan jelas melalui tabel berikut ini:

Tabel 3. Implementasi Model Behavioristik Guru Dalam Pembelajaran

\begin{tabular}{|c|c|c|}
\hline Management & Tindakan & Hasil \\
\hline $\begin{array}{l}\text { Model } \\
\text { Behavioristik }\end{array}$ & $\begin{array}{l}\text { a) Mendesain proses pembelajaran } \\
\text { mulai dari perencanaan, } \\
\text { penggorganisasian, pelaksanaan } \\
\text { dan mengevaluasi yang dituangkan } \\
\text { dalam RPP. } \\
\text { b) Menstimulus siswa secara adil, } \\
\text { memotivasi dan menginspirasi } \\
\text { dalam proses belajar mengajar, } \\
\text { serta melibatkan siswa pada } \\
\text { hubungan timbal balik secara } \\
\text { langsung. } \\
\text { c) Strategi mengatasi perilaku bias } \\
\text { pada pembelajran, pembelajaran } \\
\text { berpusat pada siswa., serta } \\
\text { pemahaman masalah siswa secara } \\
\text { adil dan bijaksana } \\
\text { d) Membelajarkan siswa } \\
\text { memiliki sikap solidaritas yang } \\
\text { tinggi dilingkungan sekolah, cintai } \\
\text { lingkungan hidup } \\
\text { mengamalkan nilai-nilai } \\
\text { religius sebagaimana KI-1. }\end{array}$ & $\begin{array}{l}\text { b) Interaksi atara guru dengan siswa berjalan } \\
\text { dengan baik dan mendapat respon yang } \\
\text { positif dari siswa, terlihat keakraban antar } \\
\text { warga sekolah. } \\
\text { c) Adanya permasalahan dalam pembelajaran } \\
\text { diatasi dengan cara yang edukatif. Siswa } \\
\text { terlibat dan meniru sesuai tema dalam } \\
\text { pembelajaran. Siswa cukup kreatif dan } \\
\text { semangat dalam pembelajaran serta } \\
\text { memberi reward yang adil dan bijaksana. } \\
\text { d) Siswa antusias dalam kegiatan "jumat } \\
\text { sodaqoh" menyisihkan uang saku mereka } \\
\text { untuk bersidaqoh, menjaga kebersihan } \\
\text { lingkungnya, hormat kepada orang yang } \\
\text { lebih tua, berdoa sebelum dan sesudah } \\
\text { belajar. }\end{array}$ \\
\hline
\end{tabular}

\section{Respon Siswa}

Optimalisasi class room managemen di madrasah ibtidaiyah (MI) membutuhkan kreatifitas guru yang sangat tinggi, secara umum dikelompokan menjadi tiga aspek yaitu, humanistik, demokratik dan behavioristik dalam proses pembelajarandi kelas III, IV,dan V MI Al Asyhar, sebagaimana data angket untuk mengetahui respon siswa terlihat pada tabel berikut, dengan ketentuan ya memiliki skor 1 (satu), dan tidak memiliki skor 0 (nol) tergambar pada tabel 4 yang dihitung dengan skor mutlak ya (skor 1) dan tidak skor (0). Persentasi respon siswa dari ketiga kelas sebagai berikut: 


\begin{tabular}{|c|c|c|c|}
\hline \multicolumn{4}{|c|}{ Tabel 4. Hasil Angket Respon Siswa } \\
\hline Aspek & Unsur-Unsur & Ya (1) & Tidak (0) \\
\hline Humanistik & $\begin{array}{l}\& \text { Sikap peduli dengan lingkungan sekitar } \\
\& \text { Memberi hadiah dan hukuman } \\
\& \text { Pembelajaran diselingi ice breaking } \\
\& \text { Merancang dengan baik lingkungan } \\
\text { belajar yang nyaman dan menyenangkan } \\
\& \text { Merubah tempat duduk sesuai dengan } \\
\text { kebutuhan pembelajaran }\end{array}$ & 56 & 6 \\
\hline Behavioristik & 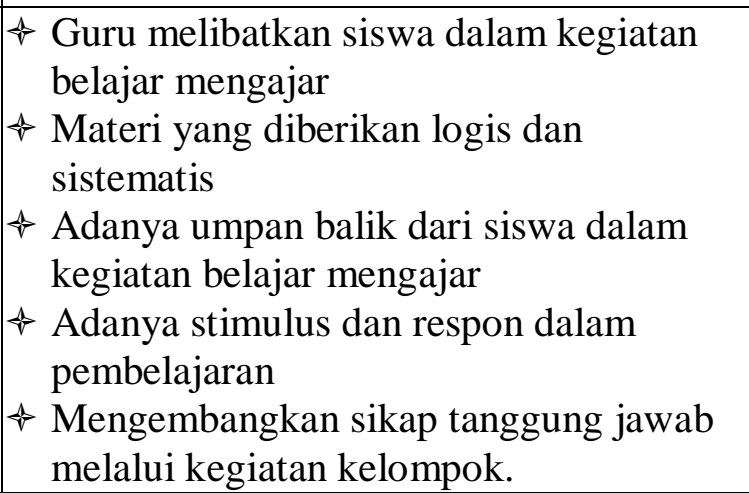 & 49 & 13 \\
\hline Demokratik & $\begin{array}{l}\text { memberi hak dan kesempatan siswa secara } \\
\text { adil }\end{array}$ & 53 & 9 \\
\hline & $\mathrm{N}=62$ & & \\
\hline
\end{tabular}

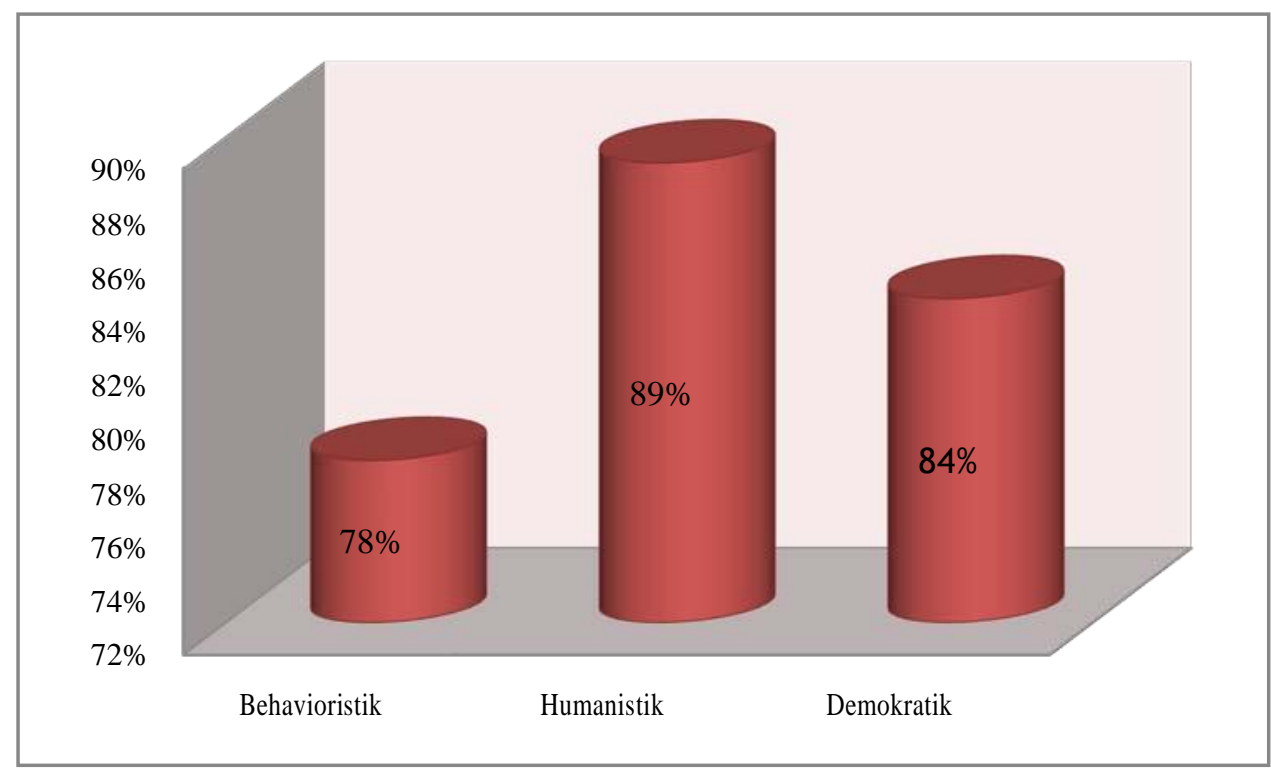

Gambar. 1. Diagram Persentasi Respon Siswa Terhadap Kreatifitas Guru Dalam Optimalisasi Class Room Management 
Dari angket siswa yang diedarkan pada 3 kelas yaitu, kelas III, IV, dan V dengan total jumlah responden $\mathrm{N}=62$ menunjukan bahwa ada sebanyak 56 siswa, angka yang paling tinggi diantara aspek yang lain. Hal ini menunjukan bahwa aspek pendekatan humanistik lebih terkondisikan dari pada aspek lainya. Ditunjukan dengan angka prosentase sejumlah $89 \%$ siswa menunjukan bahwa guru memiliki sikap peduli yang tinggi terhadap lingkungan sekitar, dengan kebutuhan dan keinginan mereka dalam proses belajar di kelas, guru juga menciptakan lingkungan kelas yang menyenangkan dengan rasa humor dan reward (hadiah) berupa pujian maupun penghargaan berupa sertifikat dan piala kepada siswa berprestasi. Umumnya hadiah selalu diumumkan secara terbuka.

Pada aspek demokratik ada sebanyak 53 siswa, artinya ada sebesar $84 \%$ siswa sepakat berpendapat bahwa guru menerapkan management kelas yang mengembangan sikap dan kemampuan siswa untuk bertanggung jawab, menerapkan kerja secara berkelompok, merotasi posisi duduk untuk mengembangkan situasi kelas secara kreatif sehingga setiap anak memiliki hak dan kesemparan secara sama. Sementara itu sebanyak 49 siswa sepakat berpendapat bahwa dalam penerapan class room management guru sering menggunakan model behavioristik karena prosentase menjukkan $78 \%$ siswa sepakat berpendapat bahwa dalam proses pembelajaran guru melibatkan mereka dalam semua kegiatan belajar, sering diberi motivasi, stimulus untuk selalu semangat dan rajin, dan pembelajarannya bisa mudah dipahami karena cukup sistematis sehingga memudahkan kegiatan belajar.

\section{Kesimpulan}

Class room management yang optimal oleh guru ialah management yang mampu mengakomodasi kebutuhan belajar siswa, mengetahui ide, persepsi, motivasi siswa sebagai subyek utama proses belajar mengajar. Sehingga dalam kreatifitas dalam menggunakan model-model management yang di gunakan mampu menciptakan lingkungan belajar yang nyaman dan menyenangkan, memfasilitasi pelaksanaan ide serta harapan yang dimiliki dan diusulkan siswa, orangtua dan sekolah karena model class room management yang dikembangkan. 
Optimalisasi class room management dengan menggunakan tiga model yaitu, humistik, demokratik dan behavioristik harus bersumber dari kepemimpinan guru yang melayani (servant leadership) sehingga ia sebagai perencana dan pelaksana pembelajaran dapat mengidentifikasi aspirasi siswa, orang tua dan lembaga sesuai dengan visi, misi dan tujuan sekolah. Evaluasi dan refleksi pembelajaran dalam class room management perlu dilaksanakan secara rutin, sehingga guru sebagai pemeran utama semakin mamahami secara teoritis dan praktis agar pembelajaran semakin berjalan dengan baik sesui tujuan pembelajaran dan harapan yang diinginkan.

\section{Daftar Pustaka}

Ary, D., Jacobs, L. C., Sorensen, C., \& Razavieh, A. (2006). Introduction to research in education (eight). Belmont: wadsworth Cengage Learning.

Dike, D., \& Parida, L. (2016). Persepsi dan konsepsi mutu pendidikan sekolah dasar. Pendidikan Dasar PerKhasa.

Scheicher, A. (2012). Preparing teachers and developing school leaders for thes 1st century: Lessons from around te world. New York: OECD Publishing.

Stake, R. E. (2005). Qualitative case studies. In N. K. Denzin \& Y. . Lincoln (Eds.), The Sage Handbook of Qualitative Research Thousand Oaks, CA.: Sage Publications Ltd. 